\title{
Sprzężenia krytyczne: antropologia, postsocjalizm, postkolonialność. Stowo wstępne
}

\section{Abstract}

\section{Introduction: Critical Connections - Anthropology, Post- socialism, Postcoloniality}

This text is an introduction to the collection of essays that address the relationship between the discipline of Anthropology, Postsocialism Studies, and the Postcolonial Thought and Scholarship. The article outlines the history of anthropological research on Postsocialism and marks the spheres of mutual influence and possible collaboration between Postcolonial Critique and the Anthropology of Postsocialism and Post-communism. It poses the question regarding the validity of time-space categorizations that frame social scientific research and theorizing about the Central and EastSouthern Europe.

Keywords: postsocialism, postcoloniality, post-communism, East-Southern Europe

Publikowane na łamach „Prac Etnograficznych” teksty są owocem panelu „Postsocjalizm i postkolonializm w refleksji i badaniach antropologicznych", który odbył się w Warszawie w październiku 2013 roku podczas I Kongresu Antropologicznego. W spotkaniu wzięli udział badacze i badaczki z Polski zajmujący się problematyką postkolonialną i/lub przemianami społeczno-kulturowymi po upadku socjalizmu państwowego w Europie i poradzieckiej Azji.

Związki łączące antropologię społeczno-kulturową z krytyką postkolonialną nie należą do łatwych. $Z$ jednej strony antropologia bywała obiektem krytyki studiów postkolonialnych jako nauka uwikłana wielorako w system kolonialny 
i imperialną praktykę polityczną (2010). Z drugiej etnografia antropologiczna dostarczała i dostarcza pogłębionych opisów ludzkiego życia, zmuszając do rewizji teoretycznych abstrakcji, do których przyzwyczaiła nas myśl postkolonialna (Ortner 2015). Uchwytne są odmienności warsztatu naukowego obu dziedzin: podstawą antropologii są intensywne badania terenowe i dążenie do zrozumienia ludzkich działań w życiu codziennym, studia postkolonialne to głównie interpretacja tekstów kultury (kanonu literatury, traktatów filozoficznych, świadectw historycznych).

Tym, co zbliża badaczy i badaczki obu obszarów, jest jednak studiowanie relacji dominacji, podporządkowania i oporu. Między antropologią a studiami postkolonialnymi zachodzi w tym zakresie nie tylko podobieństwo zamierzeń i zainteresowań, ale też pewna komplementarność. W obydwu nurtach dociekań stale pojawiają się pytania o to, jak - za pomocą jakich teorii, pojęć, obrazów, metafor - można lub powinno się myśleć i mówić o różnicach i relacjach kulturowych. Refleksję antropologiczną i postkolonialną cechuje podobne dążenie do przedstawienia doświadczenia życia z perspektywy osób i grup podporządkowanych. W obszarze studiów postkolonialnych głośne stały się badania szkoły studiów nad podporządkowanymi (Subaltern Studies [Chaturvedi 2012]), której przewodził hinduski historyk Ranajit Guha (por. Guha 2009). Antropologia znacznie rzadziej niż myśl postkolonialna zapuszczała się natomiast na teren badań nad kulturami i grupami elitarnymi, czyli tak zwanym studiowaniem do góry (Nader 1972). Refleksja postkolonialna - w szczególności prace Edwarda Saida $(2005,2009)$ stanowiła więc dla antropologów i antropolożek jedną z zachęt do badania roli naukowych praktyk poznawczych i wyobrażeniowych w tworzeniu, odtwarzaniu i przekształcaniu relacji władzy ${ }^{1}$.

Od dłuższego czasu dorobek studiów postkolonialnych jest wykorzystywany także $\mathrm{w}$ prowadzonych $\mathrm{w}$ antropologii, socjologii i kulturoznawstwie badaniach nad radykalnymi przemianami będącymi konsekwencją demontażu projektu komunistycznego i socjalizmu państwowego (zob. m.in. Buchowski 2004, 2006, 2017; Burawoy 1999; Giordano 2014; Kideckel 2009, Kürti, Skalník 2009; Verdery 2002). Ta rosnąca potrzeba poszukiwania przez antropologię przemian po socjalizmie państwowym inspiracji w studiach postkolonialnych miała dwojakie podłoże. Pierwszym była krytyczna refleksja antropologów i antropolożek nad meandrami, jakimi poruszała się antropologiczna myśl i badania nad transformacjami społeczno-ustrojowymi po upadku socjalizmu. Drugim wydaje się otwarcie pola studiów postkolonialnych na nowe obszary dociekań w obliczu końca zimnej wojny, nowych form globalności, ekspansji neoliberalnego kapitalizmu, pojawienia się radykalnych nacjonalizmów i integryzmów religijnych (Loomba, Kaul, Buntzl, Burton, Esty 2005), a zarazem trwałości pewnych form postkolonialności (Mbembe 2001).

1 Jednocześnie antropologiczne prace (np. Cohn 1996) na temat kolonializmu i systemu wiedzy/władzy kolonialnej w Indiach stanowiły inspirację dla szkoły Subaltern Studies. 
Zwycięstwo rewolucji bolszewickiej w Rosji i powstanie systemu komunistycznego to, jak zauważył filozof Alain Badiou, jedna z najbardziej radykalnych i najgłębszych zmian społecznych w całej historii ludzkości². Dlatego też rozpadu socjalizmu państwowego ponad 70 lat później nie można traktować po prostu jako kolejnego $\mathrm{z}$ wielkich i dramatycznych przełomów, w jakie obfitowało dwudzieste stulecie. Demontaż komunizmu to dekompozycja konkurencyjnej wobec kapitalizmu formy życia ekonomicznego - proces, którego następstwa mogą się okazać równie doniosłe co sama rewolucja październikowa.

Nauki społeczne i humanistyczne nie były w stanie docenić bezprecedensowości tego wydarzenia. Koniec dwudziestego wieku to okres tryumfu teoretycznego kontekstualizmu, upowszechnianie poglądu o końcu wielkich narracji i zawężenie perspektyw, rozwój różnych prądów umysłowych z prefiksami „post” lub "neo", które definiowały same siebie nie wobec antycypowanej przyszłości, lecz wcześniejszych paradygmatów i wydarzeń historycznych. Do łask powróciły między innymi idee i koncepcje, takie jak powstała w latach 50. dwudziestego wie$\mathrm{ku}$ (okres rywalizacji supermocarstw) teoria modernizacji. Jej aksjomaty, jawne i ukryte przesłanki stały się wcieloną praktyką i czymś, co można określić mianem „realnego porządku transformacji” po upadku gospodarki planowej i monopolu władzy partii komunistycznych w niektórych krajach europejskich i azjatyckich.

Przedstawiciele zachodniego świata akademickiego kładli podstawy pod plany reform i studiowali ich następstwa. Obok ekonomistów, politologów, socjologów czy psychologów, również antropolodzy prowadzili badania na temat zachodzących przeobrażeń obejmujących podstawy ustroju politycznego i gospodarczego państw, w których upadały reżimy komunistyczne. Część z nich posiadała już na ich temat wiedzę $z$ uwagi na prowadzenie wcześniej na obszarze tych krajów intensywnych antropologicznych badań terenowych (zob. Hann m.in. 1980, 1985; Humphrey 1999; Kideckel 1982; Verdery 1983).

Zrazu mogło się wydawać, że celem tych analiz jest po prostu studiowanie następstw załamania się socjalizmu państwowego i stanowienia nowego ładu ekonomiczno-politycznego na poziomie różnych lokalnych społeczności i zbiorowości. Prowadzono studia między innymi nad przemianami własnościowymi (prywatyzacją) w rolnictwie i przemyśle, procesami migracyjnymi, nowymi formami konsumpcji, polityką reprodukcyjną, społeczeństwem obywatelskim, praktykami religijnymi i tożsamością narodową. Dość szybko prace antropologów i antropolożek zajmujących się transformacją zaczęły jednak dostarczać krytycznego spojrzenia nie tylko na niknący za zakrętem dziejów socjalizm państwowy, ale również wizje i powszednie praktyki realizowania transformacji po jego upadku (Chari, Verdery 2009: 11).

W rozwijających się dynamicznie wielodziedzinowych studiach nad transformacją krytyczne wypowiedzi antropologów/antropolożek pozostawały głosem

https://www.versobooks.com/blogs/3325-alain-badiou-on-the-russian-revolution-of-october-1917 (dostęp: 07.11.2017). 
mniejszości. Jak słusznie zauważyli Michael Burawoy i Katherine Verdery, pole badawcze nowych studiów zdominowały ujęcia makrostrukturalne opisujące fundamentalne przemiany gospodarcze, polityczne, ideologiczne, pozostawiając niewiele miejsca dla charakterystycznych dla antropologii badań mikrostruktur życia codziennego w niewielkich społecznościach (1999: 1).

Osobność proponowanego przez antropologię krytycznego podejścia w studiach nad transformacją (zwanego w krajach anglosaskich „antropologią postsocjalizmu") miała oprócz metodologicznego również teoretyczne podłoże. Realny porządek transformacji przyjął kształt tak zwanej modernizacji naśladowczej. Elity władzy we wschodniej części Europy porzuciły wszelkie dążenie do eksperymentów społecznych w postaci trzeciej drogi między socjalizmem a kapitalizmem (np. w postaci demokratycznego socjalizmu), a priorytetem uczyniły naśladowanie i doganianie krajów zachodnich. Proces transformacji rozumiano teleologicznie jako zmianę kierunkową, której punkt wyjścia, kierunek i ostateczne cele są dobrze znane. Socjolog Jerzy Szacki zwięźle przedstawił myśl stojącą u podstaw koncepcji transformacji imitacyjnej: „przyszłość krajów postkomunistycznych nie kryje w sobie żadnej niewiadomej: jest nam naocznie dana jako teraźniejszość współczesnego Zachodu i chodzi nade wszystko o to, jak ją przybliżyć [...]" (Szacki 1999: 129).

Jednakże $w$ antropologii teorie modernizacji traktowano nader podejrzliwie ze względu na ich jawny elityzm i etnocentryzm (zawarte u ich podstaw przekonanie, że to Zachód - a dokładniej zachodnie elity - wyznacza jedynie słuszne wzorce procesów rozwoju społecznego) (por. Hobart 1993). Idea naśladowczej modernizacji kapitalistycznej wcielana w życie przez nowe elity polityczne, wspierane z mocą przez kręgi zachodnich i miejscowych ekspertów, spotkała się przeto w środowisku antropologicznym ze zdecydowaną krytyką (por. Baer 2009; Buchowski 2001: 9-20) ${ }^{3}$.

Realna transformacja przyjmowała zmienne politycznie postaci w zależności od miejsca i momentu (u steru rządów znajdowali się zmiennie postkomuniści, republikańscy konserwatyści, liberałowie, populistyczni nacjonaliści). Inna była dynamika zmian w Europie Środkowej, inna w Południowo-Wschodniej, jeszcze inna (i też wewnętrznie bardzo zróżnicowana) w obszarze poradzieckim. W większości miejsc, w których tranzycja stała się faktem, zmiany instytucjonalne doprowadziły tak czy inaczej do głębokich przekształceń w wielu dziedzinach

3 Krytyka ujawniała, że sami eksperci proces zmian wynikających z demontażu socjalizmu państwowego traktowali bardziej jako wielki społeczny projekt do zrealizowania niż dziesiątki problemów do opisania i wyjaśnienia. Stosowanie kategorii praktycznych używanych przez realizatorów tranzycji jako kategorii analitycznych zawężało możliwości teoretyczne i badawcze, zniechęcając do zadawania pytań o społeczne warunki możliwości i prawomocności procesów transformacji. Zrozumiała skądinąd niechęć antropologów do myślenia o przemianach w terminach teleologicznych nie powinna jednak zniechęcać do badania tranzycji jako kategorii praktyki społecznej wpływającej na sposoby działania zarówno rządzących, jak i innych grup w społeczeństwach postsocjalistycznych. 
życia, ale bynajmniej nie do szybkiego upodobnienia społeczeństw w tranzycji do zachodnioeuropejskich sąsiadów.

Antropologia postsocjalizmu koncentrowała się na kulturowych sprzecznościach i konfliktach wywoływanych zmianami w skali lokalnej, ujawniając jednocześnie niewygodne dla elit władzy oblicza transformacji. Badano zatem konsekwencje przeobrażeń $\mathrm{w}$ postaci nowych nierówności, form wykluczenia, utraty stabilności życiowej (Buchowski 1996; Dunn 2008; Kideckel 2002; Pine, Bridger 1998; Rakowski 2009; Stewart 2002), pogłębienia nierówności wcześniej istniejących (ze względu na płeć społeczną [Gal, Kligman 2000; Pine 2002]), wzrostu wzajemnej nieufności w codziennych relacjach społecznych (Giordano, Kostova 2002), napięć i konfliktów etnicznych (Buzalka 2007; Leutloff-Grandits 2006), wielorakich presji ekonomicznych i społecznych, jakim podlegali ludzie tracący pracę i wsparcie strony państwa (Kaneff 2002; Humphrey, Mandel 2002).

Antropolodzy/antropolożki postsocjalizmu ujawniali ekonomiczną i symboliczną przemoc, jaka towarzyszyła tranzycji, a także reakcję i opór ze strony wielu grup, jakie wywołały odgórnie wprowadzane i kompleksowe zmiany (Kaneff 2004). Społeczne podłoże owego oporu ujmowano zaś nie jako kłopotliwe rezyduum poprzedniego ustroju, ale jako przejaw moralnej polityki obywateli i obywatelek krajów przechodzących transformację, którzy nie godzili się na naruszanie ucieleśnionych zasad moralnych regulujących ich życie codzienne (por. Berdhal 2009; Hann 2006; Verdery 2003).

Gdy minęła pierwsza dekada przemian, częściej i mocniej zaczęły wybrzmiewać głosy podważające przydatność w badaniach antropologicznych pojęcia postsocjalizmu. Pojawiły się wątpliwości co do jego użyteczności w analizach porównawczych. Idea postsocjalizmu mogła usprawiedliwiać nie tylko wątpliwe uogólnienia, ale też fikcyjne uniwersalizacje, polegające na ujmowaniu specyficznej sytuacji, z jaką zetknął się badacz/badaczka w jednym kraju czy jego części, jako powszechnie obowiązującej we wszystkich krajach, w których socjalizm państwowy istniał i upadł po 1989 roku. Publikowany poniżej tekst Karoliny Bielenin-Lenczowskiej wskazuje, że kategoria postsocjalizmu może niebezpiecznie rozmywać różnice między poszczególnymi krajami europejskimi, w których do końca lat 80 . XX wieku panował socjalizm państwowy. Zarzut ten stawiano nie bez słuszności modelowi socjalizmu i postsocjalizmu, który zaproponowała Katherine Verdery (1996). Model ten nie uwzględnia specyficznego charakteru socjalistycznej Jugosławii - państwa, którego historia i struktura różniły się pod pewnymi względami od sytuacji w państwach satelickich Związku Radzieckiego. Dla mieszkańców byłej Jugosławii - dowodzi Bielenin-Lenczowska - to rozpad wieloetnicznej federacji i towarzyszące jej wojny, a nie sama zmiana ustroju stanowią układ odniesienia $\mathrm{w}$ rozważaniu dramatycznych zmian zachodzących w ostatnim trzydziestoleciu.

Poważne zastrzeżenia wobec idei postsocjalizmu sformułował David Kideckel (2002, 2014). Wskazywał on, że w badaniach nad postsocjalizmem zbyt wiel- 
kie znaczenie przypisuje się śledzeniu elementów ciągłości międzysystemowych i trwałości kulturowych, nie bierze zaś pod uwagę bardzo szybkiego tempa i głębokości zmian zachodzących po upadku systemu socjalistycznego. To, co wyłoniło się w wyniku "tranzycji” - argumentował badacz - trafniej byłoby określić mianem neokapitalizmu niż postsocjalizmu, a jego zasady jako - jeszcze mniej egalitarne niż obowiązujące $\mathrm{w}$ kapitalizmie zachodnioeuropejskim (Kideckel 2002: 115).

Krytyka nie zatrzymywała się na samej kategorii postsocjalizmu. Michał Buchowski w licznych publikacjach (m.in. Buchowski 2004, 2006; Buchowski, Cervinkova 2015) potępiał domyślny orientalizm polityki naukowej w anglo-amerykańskiej antropologii postsocjalizmu, nieskorej, jak argumentował, do uwzględniania $\mathrm{w}$ debacie o przemianach głosu antropologów pracujących na uniwersytetach w krajach postsocjalistycznych. Krytyczne wypowiedzi Buchowskiego odnoszące się do polityki publikacyjnej Anglosasów wybrzmiewają tym mocniej, że współgrają z szerszymi inicjatywami, takimi jak „,ruch antropologii z całego świata" (Lins Ribeiro, Escobar 2006), postulującymi zmiany w obrębie globalnej polityki naukowej - poszerzania kanonu lektur i przestrzeni dyskursu antropologicznego tak, aby lepiej odzwierciedlała zróżnicowania (genderowe, etniczne, klasowe, regionalne) występujące wśród ludzi uprawiających antropologię.

Uderzeniem w czuły nerw antropologii postsocjalizmu okazał się artykuł Tatjany Thelen (2011). Autorka wskazywała, że program ten wolny jest nie od tych samych wątpliwych założeń, które krytykuje w dyskursie i praktyce tranzytologii. Czyniąc, podobnie jak Buchowski, użytek ze słownika studiów postkolonialnych, Thelen przypisuje pewnym tekstom Verdery dotyczącym socjalizmu i postsocjalizmu coś, co nazywa „ambiwalentnym orientalizmem” (2011: 48). Perspektywa ta miałaby zakładać, że ludność krajów wschodnioeuropejskich nie różni się zasadniczo od mieszkańców zachodnich państw kapitalistycznych, niemniej podstawy instytucjonalne gospodarki kapitalistycznej czynią z niej system bardziej skuteczny, efektywniejszy niż ekonomia socjalizmu, a także postsocjalizmu. Zdaniem Thelen Verdery przyjmowała w swoich analizach milcząco normatywne i wartościujące podejście właściwe teorii neoinstytucjonalnej w ekonomii, uznające za oczywistość słabości ekonomii socjalizmu, a także niższość postsocjalizmu względem rozwiniętych i bardziej efektywnych instytucji ekonomicznych kapitalistycznego Zachodu (2011: 54).

Krytyka Thelen nie zawiera klarownej alternatywy wobec propozycji teoretycznych Verdery, chociaż wskazuje, że ukryte orientalistyczne przesłanki niektórych odmian antropologii postsocjalizmu mogą stanowić przyczynę swoistej nieoryginalności tej subdyscypliny (2011: 54). Podjęte przez nią rozważania zachęcają do przemyślenia przesłanek stojących u podstaw antropologii postsocjalizmu, w szczególności założeń na temat nierówności, a także natury relacji dominacji, podporządkowania i oporu w warunkach obecnego systemu globalnego. 
Jak na ironię to właśnie Verdery podjęła próbę systematycznego powiązania antropologicznych badań nad postsocjalizmem z polem badawczym studiów postkolonialnych (2002: 15-21). Śmiały pomysł nawiązania krytycznego dialogu między obszarami refleksji rozwijała następnie Verdery razem z Sharad Chari we wspólnym tekście pt. Thinking between the Posts: Postcolonialism, Postsocialism, and Ethnography after the Cold War (Chari, Verdery 2009).

Autorki wyróżniły trzy tematyczno-problemowe obszary potencjalnie korzystnej współpracy i przepływu idei pomiędzy studiami postkolonialnymi a antropologicznymi badaniami postsocjalizmu. Po pierwsze, oba pola badawcze mogą produktywnie wspierać się nawzajem w zakresie porównawczych analiz systemów i praktyk władzy imperialnej, a także różnych postaci społecznego oporu wobec narzuconych przez imperialne aparaty władzy form życia społecznego. W centrum uwagi znajdowałyby się mechanizmy dominacji i eksploatacji obszarów zależnych, podporządkowanych i skolonizowanych wykorzystywane dawniej i obecnie przez struktury imperialne. Jednym $z$ aspektów porównawczej analizy imperiów byłaby polityka narodowościowa i etniczna, ograniczająca, ale także niekiedy wspierająca ruchy etniczne i narodowe.

Po drugie, studia postkolonialne i postsocjalistyczne może łączyć krytyczne zainteresowanie systemami wiedzy naukowej i ich rolą w kształtowaniu zimnowojennych i pozimnowojennych stosunków międzypaństwowych. Sam podział obszarów badawczych na „postkolonialny” i „postsocjalistyczny” wydaje się, jak przekonywająco dowodzą autorki, echem zimnowojennej trychotomii segregującej glob ziemski na Pierwszy, Drugi i Trzeci Świat (2009: 18-19). Zimnowojenne rozróżnienia i klasyfikacje - ideologia Trzech Światów - stanowiły integralną część politycznej i ekonomicznej rywalizacji między reżimami modernizacyjnymi imperiów. Wiele teorii społecznych (z teorią modernizacji i teorią tranzycji na czele) można traktować jako składniki polityki wiedzy naukowej i ideologii politycznych wykorzystywanych przez imperia. Ważnym zadaniem staje się wobec tego wyjście poza te podziały i stworzenie jednolitego pola analizy systemów dominacji.

Po trzecie, warto zdaniem Chari i Verdery zwrócić uwagę na formy wykluczenia, segregacji, tak zwanego wytwarzania wrogów ludu, narodu, cywilizacji (osobliwy rasizm klasowy lub kulturowy) realizowane w epoce zimnej wojny i ich podobieństwa do systemowego czy państwowego rasizmu w USA, jak również polityki kolonialnego i neokolonialnego rasizmu prowadzonej przez mocarstwa zachodnioeuropejskie. W tym kontekście istotna byłaby analiza porównawcza polityk karceralnych i dyskryminacyjnych w imperiach ery zimnowojennej i po załamaniu się w wielu krajach socjalizmu państwowego. Autorki pytają również o perspektywy polityki oporu i praktyki nieposłuszeństwa (praktyk kontrhegemonicznych) wobec starych i nowych porządków hierarchicznych i aparatów biopolitycznych, a także szanse polityki socjalistycznej po upadku komunizmu. 
Sformułowana przez autorki tekstu propozycja powiązania studiów postkolonialnych $\mathrm{z}$ antropologią postsocjalizmu pod szyldem tak zwanych studiów postzimnowojennych nie sprowadza się bynajmniej do dostarczenia niszowym studiom nad postsocjalizmem bardziej nośnej - i upowszechnionej w zachodnim świecie akademickim - terminologii postkolonialnej. Chari i Verdery chciały osiągnąć swym tekstem więcej, kładąc nacisk na potrzebę wypracowania bardziej kompleksowego aparatu pojęciowego, pozwalającego na analizowanie stosunków dominacji i zależności w skali całego świata (por. Tulbure 2009: 6).

Omawiany artykuł nie uczynił jednakże zadania analizy przeobrażeń w krajach dawnego obozu socjalistycznego mniej uciążliwym, w szczególności nie pokazywał, w jaki sposób wypracowana (na podstawie doświadczenia i krytyki zachodniego kolonializmu) perspektywa postkolonialna miałaby się przyczynić do lepszego zrozumienia osobliwości ich obecnej sytuacji geopolitycznej i wewnętrznej (Tlostanova 2017: 11-12). Myślę, że byłoby to możliwe pod warunkiem wypracowania siatki pojęć łączącej osiągnięcia obu obszarów dociekań, przenikliwe analizy ideowego zaplecza stosunków władzy, jakie zawdzięczamy krytyce postkolonialnej z konsekwentnie prowadzonymi badaniami antropologicznymi nad specyficzną postacią zmiany społeczno-kulturowej, jaką była i jest systemowa tranzycja od socjalizmu państwowego do państwowego kapitalizmu.

Jednym $\mathrm{z}$ tropów wiodących ku takiej syntezie byłoby potraktowanie samej transformacji jako pewnego dynamicznego układu relacji władzy wiążącego wschodnioeuropejskie półperyferia z zachodnioeuropejskimi metropoliami (por. Böröcz 2010). Ujmowana $z$ takiej perspektywy struktura relacji władzy nie musi koniecznie opierać się na prostej asymetrii pomiędzy elitami a masami społecznymi. Może ona mieć charakter wielowarstwowy, włączając grupy/praktyki jednocześnie wobec pewnych grup/praktyk zdominowane, zaś wobec innych dominujące.

Co więcej, potraktowanie transformacji jako relacji władzy pozwoliłoby nam szerzej spojrzeć na stosunki dominacji i zależności. Z tej perspektywy relacje władzy jawią się nie tylko jako praktyki stabilizujące, ograniczające czy uniemożliwiające inne praktyki poprzez stosowanie wyzysku i represji, ale również jako otwieranie pewnych możliwości, jako presja ku zmianie kierunkowej. Tranzycja jako układ stosunków władzy wydaje się paradoksalnie zarówno procesem inkluzji, jak i wykluczenia, ruchem pozbawiania ludzi sprawstwa, a zarazem jego umożliwiania. Nie można zresztą postrzegać procesów transformacji tylko przez pryzmat działań, które służą ich kontestowaniu. Jak w innym kontekście przypomina James Ferguson, dążenie do adaptacji w danych warunkach i zdobycia statusu klienteli sprawujących władzę nie należy wcale do praktyk odosobnionych i nietypowych (Ferguson 2013).

Nie musi to wcale prowadzić, o czym przypomina w publikowanym tu tekście Anna Engelking, do całkowitego podporządkowania i ujarzmienia podporządkowanych. Engelking przeprowadza etnograficzną krytykę kategorii homo sovieti- 
cus - pojęcia, którym posługiwali się tacy radzieccy dysydenci, jak Aleksander Zinowiew, mogącego służyć za właściwy kolonializmowi sowieckiemu odpowiednik kategorii „człowieka skolonizowanego” lub „podporządkowanego”. Wedle Engelking homo sovieticus to pojęciowa abstrakcja niemająca odniesienia do realnych strategii przystosowawczych białoruskich kołchoźników, którzy chociaż pozbawieni własnej ziemi i wpływu na systemy władzy państwowej, wykazują jednocześnie inicjatywę i pomysłowość, mają też poczucie własnej godności i podmiotowości. Rozważając fenomen postsocjalistycznego szamanizmu buriackiego, Wojciech Połeć wprowadza charakterystyczny postkolonialny temat - kwestię skolonizowanej podmiotowości oraz trybu wyrażania przez Buriatów swego dziedzictwa kulturowego w warunkach rosyjskiego kolonializmu. Podobnie jak Engelking, Połeć uważa, że podporządkowani mogą mówić. Radzieckiej „misji cywilizacyjnej” nie udało się, jak wskazuje autor, wykorzenić praktyk szamanistycznych (szczególnie na obszarach wiejskich). Obecne odrodzenie szamanizmu wydaje się twórczym rozwinięciem pozostałości po dawnych przedrewolucyjnych praktykach.

Jak każdy układ relacji władzy, transformacja społeczno-ustrojowa jest legitymizowana i delegitymizowana jednocześnie. Trzeba wziąć pod uwagę, że relacje te niekoniecznie znajdują uprawomocnienie w schematach, podobnych do tych, które piętnował z pasją w słynnym Orientalizmie Edward Said (2005), czyli kategorycznym podziale na dominujący zachód i podporządkowany wschód Europy ${ }^{4}$. Legalizowanie stosunków władzy może opierać się na ideologii poprawy położenia społecznego zdominowanych, perspektywie społecznego awansu i mobilności strukturalnej.

Należy, jak sądzę, baczniej przyglądnąć się związkom łączącym praktyki i relacje dominacji/podporządkowania/oporu z różnymi odmianami tego, co postkolonialny historyk Dipesh Chakrabarty nazywa "polityką historycyzmu” (2008 [2000]) opartą na domyślnym historycystycznym schemacie faz, epok, momentów rozwoju społeczno-kulturowego przypisującym społeczeństwom zachodu wyższy poziom zaawansowania, innym zaś odpowiednio niższe pozycje na drabinie rozwojowej. Różnica oznacza tu nie dualizm i segregację ludzi na podstawie niezmiennie wsobnych cech, ale hierarchizacje na podstawie stanów zaawansowania i zapóźnienia w ramach pewnego kontinuum. Przykładowo: wpływowe idee misji cywilizacyjnej, nowoczesności, modernizacji ( $w$ wersji fordyzmu, modernizacji neoliberalnej lub komunistycznej), okcydentalizacji, rozwoju zrównoważonego czy tranzycji społeczno-ustrojowej na wschodzie Europy opierają się na założeniu, że różnica i nierówności między społeczeństwami czy kategoriami ludzi nie są absolutne i nieprzekraczalne, ale względne i zależne od tempa, skali i głębokości przemian społecznych w poszczególnych częściach świata.

4 Również Said w innych pracach (zob. np. Said 1985) traktuje orientalizm szerzej jako pogląd i praktykę instytucjonalną opartą na historycystycznym schemacie stadiów rozwoju społeczno-kulturowego. 
Idei tych nie trzeba też traktować wyłącznie na modłę foucaultiańską jako systemów wiedzy/władzy ujarzmiania, machin regulacji populacji i formowania tworzywa podmiotowości. Nie należą one tylko do kolonizatorów, ekspertów do spraw rozwoju i rządowych modernizatorów, ale stają się również podstawą krytyki i kwestionowania zastanych stosunków dominacji przez członków i członkinie różnych grup społecznych, także tych dyskryminowanych (por. Cooper 2005). Oczywiście polityka historycyzmu może służyć i niejednokrotnie służyła blokowaniu aspiracji i hamowaniu dążeń grup podporządkowanych, ale stanowi również podstawę mobilizacji niezadowolonych i rozczarowanych chcących osiągnąć status i warunki życia porównywalne do tych, w których żyją grupy dominujące. Toczące się w Polsce spory na temat możliwości stosowania perspektywy postkolonialnej do analizy i krytyki postsocjalizmu czy postkomunizmu (Thompson 2000; Domańska 2008; Zarycki 2014) w jakimś sensie krążą wokół problemów, jakie polityka historycyzmu tworzy, czyli potrzeby realizacji albo też oczekiwania powstrzymania określonych zmian celowych służących doganianiu przez Polskę krajów Zachodu. Jak dowodzą zresztą poniżej Magdalena Nowicka-Franczak oraz Łukasz Kaczmarek, pewne upowszechniane w Polsce formy krytyki tej polityki tworzą własne odmiany historycyzmu oparte na hierarchizacjach podobnych do tych, które są przez nie skądinąd potępiane jako przejawy zachodniego kolonializmu i orientalizmu.

Artykuły publikowane poniżej, podobnie jak niniejszy wprowadzający tekst, odzwierciedlają wątpliwości, jakich nastręczają obecnie kategorie postsocjalizmu i postkolonialności, a także inne terminy ogólne (jak np. nowoczesność, ponowoczesność lub neoliberalizm) odnoszące się do czasoprzestrzeni zdarzeń, służące wyznaczaniu specyfiki i odmienności okresów w historii ludzkiego bytowania. Terminy te wbrew pozorom nie są politycznie neutralne, pojawiają się bowiem w następstwie zaistnienia określonych stosunków władzy.

Tłem dyskusji o zasadności posługiwania się kategorią postsocjalizmu jest bowiem namysł nad periodyzacją, czasoprzestrzennymi ramami naszych opisów, analiz, krytyk i wyjaśnień. Można oczywiście zastanawiać się, czy nie zastąpić kategorii "postsocjalizm” innym terminem - lepiej pasującym do obecnych realiów w Europie Wschodniej, Środkowej i Południowo-Wschodniej. Pojawia się też inne pytanie: czy wciąż pozostawać przy myśleniu sekwencyjnym, następujących po sobie epok, zdarzeń, przełomów, czy może raczej porzucić przekonanie, że proces historyczny podlega jednej wiodącej logice sekwencji, i uznać za historykami, takimi jak Fernand Braudel (1999) czy Reinhardt Koselleck (2013), że świat jest kompozycją współistniejących z sobą, ale różniących się, jeśli chodzi o tempo i skalę, procesów zmian? Warto z pewnością przyglądać się jednocześnie relacjom/ideologiom władzy oraz procesom zmian społeczno-kulturowych (włączając periodyzacyjne kategoryzacje tych zmian), współzależnościom między nimi powstającym. To jeden z tych obszarów badań, w których współpraca antropologów i krytyki postkolonialnej zdecydowanie byłaby bardzo pożądana. 


\section{Bibliografia}

Baer M.

2009 Transformacje transformacji. O problemach antropologii postsocjalizmu, w: K. Górny, M. Marczyk (red.), Antropologiczne badania zmiany kulturowej. Społeczno-kulturowe aspekty transformacji systemowej $w$ Polsce, Wrocław.

Berdhal D.

2009 On the Social Life of Postsocialism: Memory, Consumption, Germany, Bloomington.

Böröcz J.

2010 The European Union and Global Social Change. A Critical Geopolitical-Economic Analysis, London-New York.

Braudel F.

1999 Historia i trwanie, przeł. B. Geremek, Warszawa.

Buchowski M.

1996 Klasa i kultura $w$ okresie transformacji: antropologiczne studium przypadku społeczności lokalnej w Wielkopolsce, Berlin.

2001 Rethinking Transformation: An Anthropological Perspective on Postsocialism, Poznań.

2004 Hierarchies of Knowledge in Central-Eastern European Anthropology, „The Anthropology of East Europe Review", nr 22(2), s. 5-14.

2006 The Specter of Orientalism in Europe: From Exotic Other to Stigmatized Brother, „Anthropological Quarterly”, nr 79(3), s. 463-482.

2017 Czyściec. Antropologia neoliberalnego postsocjalizmu, Poznań.

Buchowski M., Cervinkova H.

2015 On Rethinking Ethnography in Central Europe: Toward Cosmopolitan Anthropologies in the „Peripheries”, w: H. Cervinkova, M. Buchowski, Z. Uherek (eds.), Rethinking Ethnography in Central Europe, New York.

Burawoy M.

1999 Afterword, w: M. Burawoy, K. Verdery (eds.), Uncertain Transition: Ethnographies of Change in the Postsocialist World, Oxford, s. 301-312.

Buzalka J.

2007 Nation and Religion: The Politics of Commemorations in South-East Poland, Berlin.

Chakrabarty D.

2008 [2000] Provincializing Europe. Postcolonial Thought and Historical Difference, Princeton-Oxford.

Chari S., Verdery K.

2009 Thinking between the Posts: Postcolonialism, Postsocialism, and Ethnography after the Cold War, „Comparative Studies in Society and History”, nr 51(1), s. 6-34.

Chaturvedi V.

2012 Introduction, w: V. Chaturvedi (ed.), Mapping Subaltern Studies and the Postcolonial, London, s. vii-xviii.

Cohn B.

1996 Colonialism and Its Forms of Knowledge, Princeton.

Cooper F.

2005 Colonialism in Question: Theory, Knowledge, History, Princeton. 
Domańska E.

2008 Badania postkolonialne, w: L. Gandhi, Teoria postkolonialna. Wprowadzenie krytyczne, przeł. J. Serwiński, Poznań, s. 157-164.

Dunn E.

2008 Prywatyzując Polskę. O bobofrutach, wielkim biznesie i restrukturyzacji pracy, przeł. P. Sadura, Warszawa.

Ferguson J.

2013 Declarations of Dependence: Labour, Personhood, and Welfare in Southern Africa, „Journal of the Royal Anthropological Institute”, N.S. 19, s. 223-242.

Gal S., Kligman G.

2000 The Politics of Gender After Socialism. A Comparative Historical Essay, Princeton Giordano C.

2014 Does Postsocialism in Eastern Europe Mirror Postcolonialism? Grand Narratives, Myths, and Inventions about the Fall of the Berlin Wall and what Followed, w: Does East Go West?: Anthropological Pathways Through Postsocialism, Berlin, s. 225-243.

Giordano C., Kostova D.

2002 The Social Production of Mistrust [w:] Postsocialism: Ideals, Ideologies, and Practices in Eurasia, C. Hann (ed.), London-New York, s. 74-92.

Guha R.

2009 The Small Voice of History. Collected Essays, P. Chatterjee (ed.), Delhi.

Hann C.

1980 Tázlár: A Village in Hungary, Cambridge.

1985 A Village Without Solidarity: Polish Peasants in Years of Crisis, New Haven. 2006 „Not the Horse We Wanted!”: Postsocialism, Neoliberalism, and Eurasia, Berlin.

Hobart M.

1993 Introduction: the Growth of Ignorance?, w: M. Hobart (ed.), An Anthropological Critique of Development. The Growth of Ignorance, London-New York, s. 1-30.

Humphrey C.

1999 Marx Went Away - but Karl Stayed Behind, revised edition, Ann Arbor.

2002 Does the Category „Postsocialist” Still Make Sense?, w: C. Hann (ed.), Postsocialism: Ideals, Ideologies, and Practices in Eurasia, London-New York, s. 12-14.

Humphrey C., Mandel R.

2002 The Market in Everyday Life: Ethnographies of Postsocialism, w: Markets and Moralities: Ethnographies of Postsocialism, R. Mandel, C. Humphrey (eds.), Oxford - New York, s. 1-18.

Kaneff D.

2002 The Shame and Pride of Market Activity: Morality, Identity and Trading in Postsocialist Rural Bulgaria, w: R. Mandel, C. Humphrey (eds.), Markets and Moralities: Ethnographies of Postsocialism, Oxford-New York, s. 33-52.

2004 Who Owns the Past?: The Politics of Time in a 'Model' Bulgarian Village, New York-Oxford.

Kideckel D.

1982 The Socialist Transformation of Agriculture in a Romanian Commune, 1945-62, „American Ethnologist”, vol. 9, nr 2(9), s. 320-340.

2002 The Unmaking of East-Central European Working Class, w: C. Hann (ed.), Postsocialism: Ideals, Ideologies, and Practices in Eurasia, London-New York, s. 114-132. 2009 Citizenship Discourse, Globalization, and Protest: A Postsocialist-Postcolonial Comparison, „Anthropology of East Europe Review”, nr 27(2), s. 117-133. 
2014 Post-socialism as Uncertainty, Uncertainty about Post-socialism, w: C. Giordano, F. Ruegg, A. Boscoboinik (eds.), Does East Go West?: Anthropological Pathways Through Postsocialism, Berlin.

Koselleck R.

2013 Warstwy czasu. Studia z metahistorii, przeł. K. Krzemieniowa, J. Merecki, Warszawa.

Kürti L., Skalník P.

2009 Introduction: Postsocialist Europe and the Anthropological Perspective from Home, w: L. Kürti, P. Skalník (eds.), Postsocialist Europe. Anthropological Perspective from Home, New York-Oxford, s. 1-28.

Leutloff-Grandits C.

2006 Claiming Ownership in Postwar Croatia: The Dynamics of Property Relations and Ethnic Conflict in the Knin Region, Berlin.

Lins Ribeiro G., Escobar A.

2006, World Anthropologies: Disciplinary Transformations within System of Power, w: G. Lins Ribeiro, A. Escobar (eds.), World Anthropologies: Disciplinary Transformations within System of Power, Oxford-New York, s. 1-28.

Loomba A., Kaul S., Buntzl M., Burton A., Esty J.

2005 Beyond What? An Introduction w: A. Loomba, S. Kaul, M. Buntzl, A. Burton, J. Esty (eds.), Postcolonial Studies and Beyond, Durham-London, s. 1-37.

Mbembe A.

2001 On the Postcolony, Berkeley.

Nader L.

1972 Up the Anthropologist. Perspective Gained from Studying up, w: D. Hymes (ed.), Reinventing Anthropology, New York, s. 284-311.

Ortner S.

2015 Opór i problem etnograficznej odmowy, przeł. A. Pasieka, w: A. Pasieka, K. Zielińska (red.), Opór i dominacja. Antologia tekstów, Kraków, s. 145-158.

Pine F.

2002 Retreat to the Household? Gendered Domains in Postsocialist Poland, w: Postsocialism: Ideals, Ideologies, and Practices in Eurasia, C. Hann (ed.), London-New York, s. 95-113.

Pine F., Bridger S.

1998 Introduction: Transitions to Post-socialism and Cultures of Survival, w: S. Bridger, F. Pine (eds.), Surviving Post-Socialism. Local Strategies and Regional Responses in Eastern Europe and Former Soviet Union, London-New York, s. 1-15.

Rakowski T.

2009 Łowcy, zbieracze, praktycy niemocy. Etnografia człowieka zdegradowanego, Gdańsk.

Rea W.

2010 Anthropology and Postcolonialism, w: S. Chew, D. Richards (eds.), A Concise Companion to Postcolonial Literature, Oxford, s. 182-203.

Said E.

1985 Orientalism Reconsidered, „Cultural Critique”, nr 1, s. 89-107.

2005 Orientalizm, wyd. II, przeł. M. Wyrwas-Wiśniewska, Poznań.

2009 Kultura i imperializm, przeł. M. Wyrwas-Wiśniewska, Kraków.

Stewart M. 
2002 Deprivation, the Roma, and „the Underclass”, w: C. Hann (ed.), Postsocialism: Ideals, Ideologies, and Practices in Eurasia, London-New York, s. 133-156.

Szacki J.

1999 Nauki społeczne wobec wielkiej zmiany, w: J. Kurczewska (red.), Zmiana społeczna. Teorie i doświadczenia polskie, Warszawa.

Thelen T.

2011 Shortage, Fuzzy Property and other Dead Ends in the Anthropological Analysis of (Post)socialism, „Critique of Anthropology”, nr 31(1), s. 43-61.

Thompson E.

2000 Trubadurzy imperium. Literatura rosyjska i kolonializm, przeł. A. Sierszulska, Kraków.

Tlostanova M.

2017 Postcolonialism and Postsocialism in Fiction and Art, London.

Tulbure N.

2009 Introduction to Special Issue: Global Socialisms and Postsocialisms, „Anthropology of East Europe Review", nr 27(2), s. 2-18.

Verdery K.

1983 Transylvanian Villagers: Three Centuries of Political, Economic, and Ethnic Change, Berkeley.

1996 What Was Socialism and What Comes Next?, Princeton.

2002 Whither Postsocialism?, w: C. Hann (ed.), Postsocialism: Ideals, Ideologies, and Practices in Eurasia, London-New York, s. 15-28.

2003 The Vanishing Hectare: Property and Value in Postsocialist Transylvania, New York.

Zarycki T.

2014 Ideologies of Eastness in Central and Eastern Europe, New York. 